\title{
Quantitative PCR assay to determine prevalence and intensity of MSX (Haplosporidium nelsoni) in North Carolina and Rhode Island oysters Crassostrea virginica
}

\author{
Ami E. Wilbur ${ }^{1, *}$, Susan E. Ford ${ }^{2}$, Julie D. Gauthier ${ }^{3}$, Marta Gomez-Chiarri ${ }^{4}$ \\ ${ }^{1}$ Department of Biology and Marine Biology, Center for Marine Science, University of North Carolina Wilmington, \\ 5600 Marvin K. Moss Lane, Wilmington, North Carolina 28409, USA \\ ${ }^{2}$ Rutgers University, Haskin Shellfish Research Laboratory, 6959 Miller Avenue, Port Norris, New Jersey 08349, USA \\ ${ }^{3}$ Department of Biology, Loyola University, New Orleans, 6363 St. Charles Ave., New Orleans, Louisiana 70118, USA \\ ${ }^{4}$ Department of Fisheries, Animal and Veterinary Science, University of Rhode Island, \\ CBLS Room 169, Kingston, Rhode Island 02881, USA
}

\begin{abstract}
The continuing challenges to the management of both wild and cultured eastern oyster Crassostrea virginica populations resulting from protozoan parasites has stimulated interest in the development of molecular assays for their detection and quantification. For Haplosporidium nelsoni, the causative agent of multinucleated sphere unknown (MSX) disease, diagnostic evaluations depend extensively on traditional but laborious histological approaches and more recently on rapid and sensitive (but not quantitative) end-point polymerase chain reaction (PCR) assays. Here, we describe the development and application of a quantitative PCR (qPCR) assay for $H$. nelsoni using an Applied Biosystems TaqMan ${ }^{\circledR}$ assay designed with minor groove binder (MGB) probes. The assay was highly sensitive, detecting as few as 20 copies of cloned target DNA. Histologically evaluated parasite density was significantly correlated with the quantification cycle $\left(\mathrm{C}_{\mathrm{q}}\right)$, regardless of whether quantification was categorical $\left(\mathrm{r}^{2}=0.696, \mathrm{p}<0.0001\right)$ or quantitative $\left(\mathrm{r}^{2}=0.797, \mathrm{p}<\right.$ 0.0001). Application in field studies conducted in North Carolina, USA ( 7 locations), revealed widespread occurrence of the parasite with moderate to high intensities noted in some locations. In Rhode Island, USA, application of the assay on oysters from 2 locations resulted in no positives.
\end{abstract}

KEY WORDS: MSX · Oysters · qPCR · Diagnostic assay $\cdot$ Histology $\cdot$ Parasite density

\section{INTRODUCTION}

The use of polymerase chain reaction (PCR) assays for detecting parasites of commercially important bivalves has progressed from initial development (Anderson et al. 1995, Stokes et al. 1995, Robledo et al. 1998, Penna et al. 2001, Carnegie et al. 2003) to implementation in field studies (Lyons et al. 2005, Carnegie et al. 2008, Tun et al. 2008, Ford et al. 2009a) and is beginning to be used for seed certifica- tion (e.g. Ford et al. 2009b). The greater sensitivity of PCR, compared to histology or other non-molecular semi-quantitative assays for bivalve pathogens, has been demonstrated repeatedly in these studies. This improved sensitivity has resulted in detection of the presence of a parasite (or parasite DNA) when more traditional histological methods were unable to detect its presence (Ford et al. 2009a). PCR assays allow recognition of target DNA regardless of the life stage present; they can be used to detect cryptic life 
history stages in atypical hosts, vectors, and/or environmental samples, and they provide a sensitive tool for detecting the pathogens at early stages of infection.

Traditional PCR assays analyze end-point amplification products that generally require post-amplification handling for quantification, reducing their utility for some questions. These limitations have prompted interest in real-time or quantitative PCR (qPCR) assays, which have followed a trajectory similar to end-point PCR, from initial development as a diagnostic tool (Day et al. 2000, Yarnall et al. 2000, Audemard et al. 2004, Gauthier et al. 2006, Lyons et al. 2006, De Faveri et al. 2009) to application for understanding the ecology of the parasite in the environment, and mechanisms of host-pathogen interactions (Audemard et al. 2006, Marty et al. 2006, Gast et al. 2008, Liu et al. 2009). These applications have been made possible by the fact that qPCR assays permit the absolute or relative quantification of the target. For species of parasites that can be propagated in vitro, a qPCR assay can be calibrated using counts of cultured parasites (Yarnall et al. 2000, Audemard et al. 2004, Gauthier et al. 2006, De Faveri et al. 2009) to convert relative to absolute abundance. The inability to propagate some important bivalve pathogens complicates the development of qPCR assays for those pathogens. In such cases, calibration can be achieved by using semi-quantitative rating systems for infection intensity (Corbeil et al. 2006, Marty et al. 2006) or serial dilutions of cloned targets (Ulrich et al. 2007a, Liu et al. 2009).

One of the parasites for which in vitro propagation has remained problematic is Haplosporidium nelsoni, the causative agent of multinucleated sphere unknown (MSX) disease in eastern oysters Crassostrea virginica. MSX disease was responsible for catastrophic oyster mortalities in the mid-Atlantic US states in the late 1950s and early 1960s. Widespread and recurrent mortalities persisted in the Delaware and Chesapeake Bays, and by the 1980s, H. nelsoni had been reported in oysters from Maine to Florida (Haskin \& Andrews 1988). Outside the mid-Atlantic, however, the impact of the parasite has been more uncertain, with its presence not necessarily being associated with extreme mortalities. To the north, the lack of epizootic outbreaks was temporary, with severe mortalities being reported subsequently from Long Island Sound, USA, to Nova Scotia, Canada (Matthiessen et al. 1990, Barber et al. 1997, Sunila et al. 1999, Stephenson et al. 2003). To the south, the prevalence of histologically detected $H$. nelsoni infections has remained low since quantitative data collections began in the mid-1980s (Lewis et al. 1992, Dougherty et al. 1993, Bobo et al. 1996). For this study, we targeted one area in the northern range (Rhode Island) and one in the southern range (North Carolina), where relatively little information exists on the distribution and prevalence of $H$. nelsoni.

In North Carolina, the first reports of Haplosporidium nelsoni date to the early1960s when the parasite was found in Pamlico Sound oysters (Haskin \& Andrews 1988), but the epizootic mortalities associated with the pathogen just to the north, in Chesapeake Bay, apparently did not occur, or at least were not reported. In fact, the potential association of $H$. nelsoni with oyster mortalities was not investigated until the fall of 1988, when large-scale mortalities prompted the testing of oysters from 11 locations in North Carolina. At that time, only 2 sites were found to be positive by histological examination for $H$. nelsoni (Fig. 1, Crab Slough and Wysocking Bay), whereas oysters from 9 sites exhibited infections with Perkinsus marinus (cause of Dermo disease) to which the mortalities were attributed (NCDMF 2008). A more expansive survey of oysters in the fall of 1989, using the hemolymph assay of Burreson et al. (1988), indicated that $H$. nelsoni was more widespread in North Carolina, with oysters from 11 of 36 locations exhibiting detectable infections (Morrison et al. 1992). The sites where $H$. nelsoni was reported were restricted to the

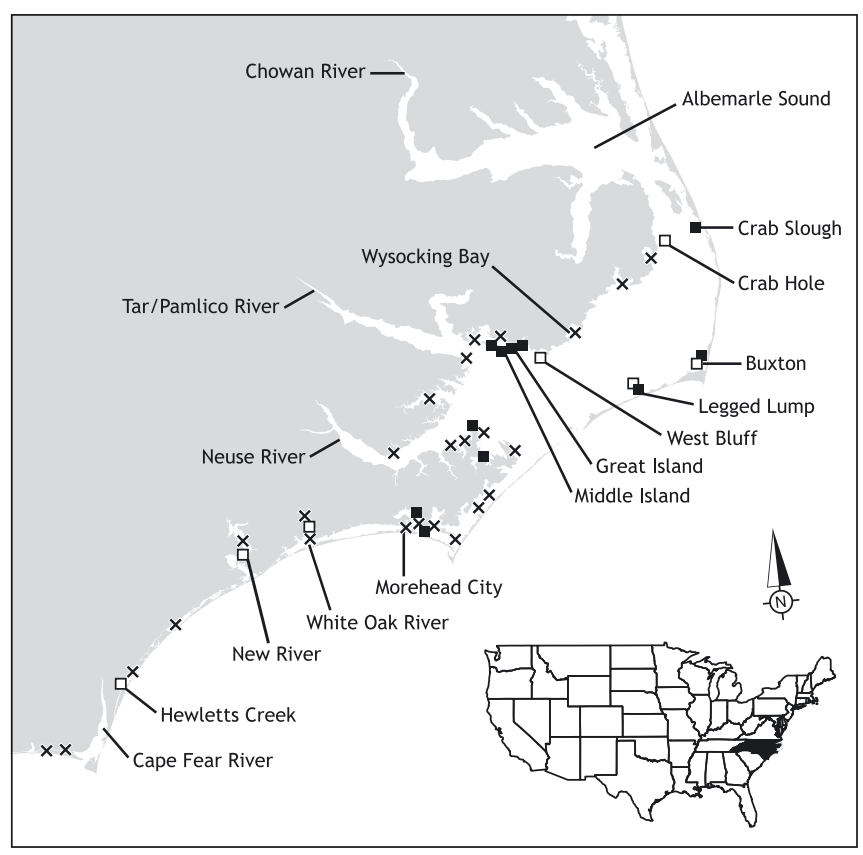

Fig. 1. Sample locations in North Carolina, USA, tested for Haplosporidium nelsoni. Sample sites where $H$. nelsoni was detected ( $\square$ ) or not detected $(\times)$ by Morrison et al. (1992). (ㅁ) Sites sampled for this study 
northern waters of the state, with the southernmost occurrence being in the Newport River near Morehead City. At only 2 sites (near the mouth of the Pamlico River, see Fig. 1) were the infections deemed substantial (11 of 40 oysters infected from Great Island, 12 of 43 from Middle Ground, with infections ranging from 1 to 1000 plasmodia per 100000 hemocytes; Morrison et al. 1992). Subsequent sampling conducted during 1990 to 1992 revealed no high-intensity infections, and severe hurricane activity in the mid-1990s, which kept salinities low, was suggested as the reason that $H$. nelsoni has not proliferated in the Pamlico River (NCDMF 2008).

Similarly, Rhode Island oysters have likely experienced some infection pressure from Haplosporidium nelsoni since the 1960s, when the parasite was reported in the adjacent states of Connecticut and Massachusetts (Krantz et al. 1972, Haskin \& Andrews 1988), but the extent of oyster morbidity and mortality caused by this parasite is unknown. A survey in the 1980s failed to find the parasite (Cooper \& Durfee 1982), but $H$. nelsoni was observed in oysters from a coastal pond in Rhode Island in another survey performed in 1991 to 1992 (Andamari et al. 1996). A state-funded annual monitoring program that began in 1998 using a combination of histology and PCR (Stokes et al. 1995) determined that the prevalence of haplosporidian parasites in Rhode Island oysters is usually low and restricted to a few locations (Alves 2007). The highest levels of infection were observed in 1998, coincident with the timing of an MSX-disease epizootic experienced by Connecticut oysters in 1997 to 1998 (Sunila et al. 1999). It is unclear, however, whether the heavy mortalities observed in wild oyster populations in Rhode Island at this time were due to MSX or to Dermo disease, which is prevalent in wild oysters.

The differences in the progression of the hostparasite relationship in epizootic areas and those where epizootics are rare or have not been reported raise questions regarding the factors that trigger or inhibit MSX disease outbreaks. The expansion of oyster restoration and aquaculture in both North Carolina and Rhode Island increases the need to understand what can cause the shift from an apparently benign relationship (present without epizootic mortalities) to a more deleterious one. It may be that the relationship remains benign as long as infective stages are scarce, the oysters are resistant, or the parasite has reduced virulence. The parasite could be scarce because of an environmental condition (i.e. recurring low salinity) or low abundance of an alternate or immediate host (Ford et al. 2009b). Evidence contradicts the hypothesis that oysters in these regions are resistant to MSX disease, as they become heavily infected when transplanted to known epizootic waters (Ford \& Haskin 1987, Ragone-Calvo et al. 2003). The inability to culture Haplosporidium nelsoni has restricted investigation of variation in its virulence.

We developed a qPCR assay for Haplosporidium nelsoni that will allow the rapid and quantitative detection of parasites in monitoring programs, as well as facilitate the study of MSX disease epizootiology. We calibrated the assay against different measures of parasite abundance: (1) cloned H. nelsoni DNA copy number, (2) a semi-quantitative rating system, and (3) estimates of parasite density made using counts of $H$. nelsoni in histological sections. The assay was tested in 2 different laboratories, using 2 different platforms, and samples from 7 populations of oysters in North Carolina and 2 sites in Rhode Island.

\section{MATERIALS AND METHODS}

\section{Assay development}

The MSX assay was developed as a TaqMan ${ }^{\circledR}$ assay with a minor groove binder (MGB) probe and was designed to target a relatively non-conserved region within the small subunit ribosomal RNA (SSU rRNA) gene of Haplosporidium nelsoni (Fong et al. 1993). TaqMan ${ }^{\circledR}$ assays incorporate specific forward and reverse PCR primers to amplify a short amplicon $(\sim 150 \mathrm{bp})$ and an internal probe constructed with a 5' fluorescent reporter dye, a 3' quencher, and an MGB tail to increase the stringency (Kutyavin et al. 2000). The components of this assay were designed using Primer Express software Version 2.0 (Applied Biosystems), and the target region was selected because of the substantial number of mismatches between $H$. nelsoni and other protozoan organisms known to exist within or around oysters. The primer and probe sequences for the MSX assay were as follows: forward primer: 5'-GCG CGC TAC AAT GTT GCA-3'; reverse primer 5'-CGA GAT TAC CCG GCC TTC TC-3'; and 6-carboxyfluorescein (FAM)labeled MGB probe: 5'-CGA GTT CAA CCT TGC C-3'. TaqMan MGB assay technology is designed to detect $\geq 1 \mathrm{bp}$ discrepancies within the probe region; therefore, a false positive signal is highly unlikely when mismatches of $\leq 2 \mathrm{bp}$ occur. The MSX assay specificity was empirically tested against $H$. costale and other oyster protozoan pathogens known to 
occur in North Carolina or Rhode Island waters (Bonamia spp., Perkinsus marinus). The assay was also tested using gametes from 12 oysters collected in 2010 (6 each from Tampa Bay, Florida, and Barataria Bay, Louisiana) to further evaluate the potential for false positives. Oysters in these areas are presumed to be free of $H$. nelsoni as determined using histology, end-point PCR, or both (Kim \& Powell 2007, Ford et al. 2011). All 12 samples were evaluated in North Carolina. In Rhode Island, 6 Barataria Bay samples and 1 Tampa Bay sample were tested.

\section{Assay calibration/validation}

Haplosporidium nelsoni has not been successfully propagated in vitro, preventing the calibration of the qPCR assay against absolute parasite numbers. We therefore applied 3 approaches for evaluating infection in order to calibrate the assay: cloned gene target, a categorical rating of infection based on histological examination, and quantification of parasite densities from histological examination.

\section{Cloned SSU rRNA target}

Primers were designed using Primer3 (Rozen \& Skaletsky 2000) to amplify a 237 bp fragment (1391 F 5'-GTG ATG CAG CAG ATG GAA GA-3'; 1627 R 5'-GTA CAA AGG GCA GGG ACG TA-3') of the Haplosporidium nelsoni SSU rRNA sequence (Fong et al. 1993) containing the target region. PCR $\left(94^{\circ} \mathrm{C}\right.$ for $3 \mathrm{~min}, 24$ cycles of $94^{\circ} \mathrm{C}$ for $1 \mathrm{~min}, 58^{\circ} \mathrm{C}$ for $1 \mathrm{~min}$, $72^{\circ} \mathrm{C}$ for $2 \mathrm{~min}$, followed by $72^{\circ} \mathrm{C}$ for $5 \mathrm{~min}$ ) was conducted using $2 \mu \mathrm{l}$ of template $\left(\sim 0.5 \mu \mathrm{g} \mathrm{ml}^{-1}\right.$ DNA from North Carolina oysters heavily infected with $H$. nelsoni). The product was captured in pGEM ${ }^{\circledR}$ - $\mathrm{T}$ Easy vector (Promega) and cloned in EC100 Transformax Electrocompetent cells (Epicentre) for blue-white colony selection on Amp-100 (100 $\mathrm{gg} \mathrm{ml}^{-1}$ Ampicillin) Luria-Bertani agar plates according to the pGEM-T Easy protocol. White colonies were screened for inserts using the above primers, cells were grown overnight in Amp-100 LB (Luria-Bertani broth), and plasmid was isolated using Qiagen Mini-Prep reagents and protocol. The cloned SSU rRNA target was serially diluted, and duplicate reactions run for cloned target alone and cloned target spiked into $200 \mathrm{ng}$ (routine assay concentration) of oyster DNA from an uninfected oyster. qPCR was performed as described below. A cloned SSU rRNA target was also prepared in Rhode Island using a local infected sam- ple and similar conditions, with the exception that the PCR fragment was cloned using the TOPO TA cloning kit (Invitrogen) following the manufacturer's instructions. Concentration of the plasmid including the cloned target was determined using a Nanodrop 8000 (Thermo Scientific), and copy numbers were determined using the size of the plasmid.

Histological quantification of parasite densities

Susceptible oysters exposed to Haplosporidium nelsoni in enzootic waters of New Jersey and selected oysters collected by the Rhode Island disease monitoring program were selected for comparison of histological and qPCR assays. The New Jersey oysters were shucked by breaking the hinge attachment with an oyster knife, then severing the adductor muscle from the valves. The tissues were rinsed in tap water to remove bits of sand and shell. A $5 \mathrm{~mm} \mathrm{sec-}$ tion across the visceral mass and gill was removed, placed posterior side down in a cassette, and fixed in Davidson's fixative. A second section of gill immediately posterior to the histological section, approximately $2 \mathrm{~mm}$ wide and including all 4 demibranchs, was removed and fixed in $95 \%$ ethanol (EtOH) for qPCR analysis. A second piece of tissue, from the visceral mass and also immediately posterior to the histology section, was preserved separately in 95\% EtOH. Shucking knives were rinsed in tap water and then in bleach solution between oysters, and dissecting instruments were dipped in $70 \% \mathrm{EtOH}$ and then flamed between tissues. The histological sections were embedded in paraffin, processed into tissue slides using standard methods, and stained with hematoxylin and eosin. The orientation of embedded tissue was such that the histology and qPCR tissues were as close as possible to each other. Tissues fixed for $\mathrm{qPCR}$ were stored at $-20^{\circ} \mathrm{C}$ until shipped overnight on ice from the Haskin Shellfish Research Laboratory to the University of North Carolina Wilmington. Rhode Island oysters were processed similarly, with the exception that tissues for qPCR were collected prior to collection of the histological sections without considering proximity to the histological section. Samples of gills, visceral mass, and mantle from each oyster were stored in the same tube containing $95 \%$ EtOH.

Stained sections were screened for the presence of Haplosporidium nelsoni, and the infections were scored from 0 to 6 based on categories established by Ford \& Haskin (1982) (Table 1). Forty-five oysters from New Jersey were selected to encompass the 
span of infection intensities observed, which ranged from rare (a single plasmodium detected) to very heavy. All 45 sections contained plasmodia (the multinucleate stage of $H$. nelsoni most often found in oysters) in the gills; 12 also had infections in the visceral mass. These 57 samples were further analyzed by both histology and qPCR. An additional 15 samples in which no infections were detected histologically were also analyzed by qPCR.

Estimation of parasite density was performed as follows. For each section, plasmodia were counted using a gridded ocular placed randomly over the tissues (at least 5 over each demibranch for gill infections). In most samples, tissues were viewed with a $25 \times$ objective, and at least $20(40 \times 40 \mu \mathrm{m})$ grids were counted in the gill and 20 in the visceral mass. The number of grids counted increased when tissues were lightly infected to increase the chances of encountering plasmodia. Some very heavily infected tissues were examined with a $100 \times$ objective and 60 $(10 \times 10 \mu \mathrm{m})$ grids were counted. A correction was made to account for sections in the gill where a portion of the grid fell over a non-tissue space by counting the number of intersections within the grid that fell over tissue and standardizing the plasmodial count to the total possible 16 intersections. Standardized plasmodial counts were averaged and multiplied by the area of the grid and the thickness of the section $(6 \mu \mathrm{m})$ to calculate a mean parasite per $\mu \mathrm{m}^{3}$ of fixed tissue. This value was then divided by 2 to correct for the fact that Haplosporidium nelsoni plasmodia are generally greater than $6 \mu \mathrm{m}$ in diameter and would be expected to fall into 2 consecutive sections. The final numbers were then multiplied by 0.9

Table 1. Haplosporidium nelsoni. Descriptive evaluations of categories for infections assessed by tissue-section histology. $\mathrm{N}$ : none, no parasites found in the section; R: rare, 10 parasites in entire section; VL: very light, 11 to 100 parasites in the entire section; L: light, $>100$ parasites per section, but averaging fewer than 1 per $1000 \times$ field; M: moderate, averaging 1 to 5 parasites per field; $\mathrm{H}$ : heavy, averaging $>5$ parasites per field

\begin{tabular}{|llc|}
\hline Category & Distribution & Intensity rating \\
\hline 0 & - & $\mathrm{N}$ \\
1 & Epithelial & $\mathrm{R}$ \\
2 & Epithelial & $\mathrm{VL}, \mathrm{L}$ \\
3 & Subepithelial/local & $\mathrm{L}, \mathrm{M}^{\mathrm{a}}$ \\
4 & Systemic & $\mathrm{L}$ \\
5 & Systemic & $\mathrm{M}$ \\
6 & Systemic & $\mathrm{H}$ \\
& \\
${ }^{a}$ Can be locally & \\
\hline
\end{tabular}

to correct for an estimated $10 \%$ volume shrinkage upon fixation. The result, converted to $\mathrm{cm}^{3}$ was considered an estimate of parasites $\mathrm{g}^{-1}$ wet weight (wet $\mathrm{wt}$ ), as the specific gravity of oyster tissue is approximately $1 \mathrm{~g} \mathrm{~cm}^{-3}$ (Andrews 1961). Three gill sections contained only 1 or 2 detected plasmodia and were assigned a parasite density of $10^{-4} \mathrm{~g}^{-1}$ wet wt based on previous calculations suggesting that value as the minimum density that can be reliably detected by tissue section histology (Ford et al. 1999). Samples used in Rhode Island for the calibration of the assay were selected from an archive of 29 pools of gill, mantle, and digestive tissue or DNA samples from oysters collected in 2007 and 2008 from 7 subtidal locations and with known levels of $H$. nelsoni as determined by histology (Farley 1968) and end-point PCR (Stokes et al. 1995).

\section{DNA extractions}

Tissue samples analyzed in North Carolina were extracted using a PureGene ${ }^{\mathrm{R}}$ Extraction kit (Qiagen) as described by Gauthier et al. (2006). DNA concentration $\left(\mu \mathrm{g} \mu \mathrm{l}^{-1}=\right.$ absorbance at $260 \mathrm{~nm}\left[A_{269} \mathrm{~nm}\right] \times$ $0.05 \times$ dilution factor) was determined on a Genesys $^{\mathrm{TM}} 8$ spectrophotometer, and all samples were adjusted to $100 \mathrm{ng}^{-1}$ prior to qPCR analysis. The 260:280 $\mathrm{nm}$ absorbance ratio was used to determine the purity of DNA and was between 1.8 and 2.0 for all samples assayed. Extracts tested as part of the assay application were also used in genetic analysis (16s mitochondrial gene sequencing and microsatellites) validating the effectiveness of the extraction process in yielding amplifiable DNA. DNA from the tissue samples from Rhode Island oysters was isolated using the Chelex protocol as previously described (DeFaveri et al. 2009), and subsequent analysis implementing an internal control has produced no indication of qPCR inhibition in samples extracted in this manner.

\section{qPCR assay conditions and application}

qPCR was performed using 2 different platforms: the ABI 7500 Real-Time PCR System (Applied Biosystems) in North Carolina and the Roche LightCycler ${ }^{\circledR} 480$ real-time qPCR (Roche Applied Science) in Rhode Island. Common reagents for both platforms included the primers and the probe (see above, Applied Biosystems). For the ABI platform (North Carolina samples), reagents were added in 
the following proportions to each well of 96-well optical reaction plates (ABI 4306737): $12.5 \mu \mathrm{l}$ MasterMix (ABI 4324018), $1.25 \mu$ l primer+probe mixture (ABI 4331348: reaction concentrations were $900 \mathrm{nM}$ for each primer and $250 \mathrm{nM}$ for the probe), $9.25 \mu \mathrm{l}$ double-distilled water $\left(\mathrm{ddH}_{2} \mathrm{O}\right)$, and $2 \mu \mathrm{l}$ of template (100 ng $\mathrm{ul}^{-1}$ ) for a $25 \mu \mathrm{l}$ reaction volume. Plates were sealed with MicroAmp ${ }^{\circledR}$ optical strip caps (ABI 4323032), and reactions were run on an ABI 7500 Real-Time PCR System using the ABI 7500 System SDS Software with the default temperature program $\left(95^{\circ} \mathrm{C}\right.$ for $10 \mathrm{~min} ; 40$ cycles of $95^{\circ} \mathrm{C}$ for $15 \mathrm{~s}$ followed by $60^{\circ} \mathrm{C}$ for $1 \mathrm{~min}$ ) for a total run time of $1.5 \mathrm{~h}$. Positive and negative controls were included in every run. Positive controls were 3 oysters that were previously determined to show a range of infection intensities and were included to assess the consistency of assay performance across runs. The negative controls were spiked with sterile water instead of DNA.

Each reaction for the Roche platform (Rhode Island samples) included $10 \mu$ l of LightCycler ${ }^{\circledR} 480$ Probes Master mix (Roche), $1.2 \mu \mathrm{l}$ of each primer (IDT DNA, $600 \mathrm{nM}$ final concentration), $0.5 \mu \mathrm{l}$ probe (final con-

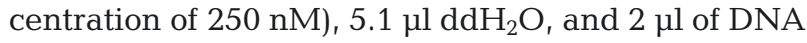
template for a $20 \mu \mathrm{l}$ reaction volume. Reactions were run on a Roche LightCycler ${ }^{\circledR} 480$ real-time qPCR system $\left(95^{\circ} \mathrm{C}\right.$ for $5 \mathrm{~min} ; 40$ cycles of $95^{\circ} \mathrm{C}$ for $15 \mathrm{~s}$ followed by $60^{\circ} \mathrm{C}$ for $\left.1 \mathrm{~min}\right)$. The controls in the Rhode Island runs included 2 oysters previously determined by histology to be positive, and the negative control was sterile water. A standard curve of dilutions from cloned DNA was also included in each Rhode Island qPCR run.

Results of the amplifications are reported as a quantification cycle $\left(\mathrm{C}_{\mathrm{q}}\right.$; Bustin et al. 2009), which is representative of the number of cycles required for target amplification to reach the exponential phase and thus is inversely related to the initial concentration of the target in the sample.

Oysters were collected from subtidal reefs from 4 locations ( $\mathrm{n}=15$ each site, 60 total) in Pamlico Sound in July 2006 and from 3 intertidal locations ( $\mathrm{n}=90$ each site, 270 total) in southeastern North Carolina in December 2006 (Fig. 1). Oysters were measured (shell height) and shucked, and a small ( 15 mg) piece of mantle was dissected and frozen for later DNA extraction following the protocols described above. In Rhode Island, a total of 107 samples collected at 2 farm locations (Portsmouth and Rome Point) in 2009 were tested by qPCR. Of those, 38 samples were also tested using end-point PCR (Stokes et al. 1995).

\section{RESULTS}

\section{Specificity of the assay}

Primer and probe sequences were aligned with SSU rRNA gene sequences from 22 taxa (GenBank accession numbers: Haplosporidium costale, U20858; H. edule, DQ458793; H. montforti, DQ219484; H. lusitanium, AY449713; H. louisiana, U47851; unknown Haplosporidium spp., AY781176, AY435093, AY449712, AF492442, DQ653412, AY449715, DQ444238; Minchinia chitonis, AY449711; Minchinia sp., EF165631; M. teredinis, U20319; M. tapetis, AY449710; Urosporidium crescens, U47852; Urosporidium sp., AY449714; Bonamia ostrea, AF262995; Bonamia sp., AY542903; B. perspora, DQ356000; and B. exitiosa, DQ312295). The average number of mismatches between the assay sequences and the non-target taxa was 17 , with the differences, in general, being distributed across the primers and the probe. The fewest mismatches (7) were seen between the designed assay and an undescribed halosporidian isolated from a polychaete (Siddall \& Aguado 2006), but the presence of 4 differences in the probe sequence is likely to result in no false positives attributable to co-occurrence of this parasite. Empirically, the assay as performed in North Carolina produced no signal in oyster tissues infected with Perkinsus marinus or Bonamia spp. In Rhode Island, at least 3 samples with moderate $P$. marinus infections were included among samples tested using the $H$. nelsoni qPCR and were negative. One oyster sample (provided by the OIE reference laboratory at the Virginia Institute of Marine Science) and 2 from Rhode Island that were positive for $H$. costale, as determined by histology and end-point PCR (Stokes \& Burreson 2001), were negative by qPCR.

The Gulf of Mexico samples were treated as biologically relevant negative controls, since these samples are from an area where Haplosporidium nelsoni has not been found. A recent report of the PCR detection of $H$. nelsoni in oysters from the Gulf coast (Ulrich et al. 2007b) was not supported by histological analysis, nor did a subsequent survey using both PCR and histology (Ford et al. 2011) verify the 2007 report. Further, the Gulf samples used in the present study consisted of gametes that were removed by pipette from underneath the mantle, minimizing the possibility of detecting parasites that might be adhering to external surfaces. When tested for $H$. nelsoni using qPCR, 4 of 12 samples tested in North Carolina exhibited $\mathrm{C}_{\mathrm{q}}$ values between 38.89 and 39.93 (mean \pm SD: $39.6 \pm$ 
0.45), and the remaining 8 did not amplify. In Rhode Island, all of the Gulf samples showed $\mathrm{C}_{\mathrm{q}}$ values ranging between 30.18 and 34.78 (31.8 \pm 1.54). Therefore, a cut-off $\mathrm{C}_{\mathrm{q}}$ value of 38 (for the ABI platform) and 30 (for the Roche platform) was used to designate positive samples.

\section{Assay validation/calibration}

\section{Cloned SSU rRNA target}

Cloned target was serially diluted and assayed on the ABI platform alone and in the presence of $200 \mathrm{ng}$ of oyster DNA from samples determined to be negative for Haplosporidium nelsoni by histology and qPCR. Duplicate reactions of each treatment (alone, Fig. 2; and in the presence of oyster DNA, data not shown) were assayed and the resulting $\mathrm{C}_{\mathrm{q}}$ values regressed against log template copy number. The regressions did not differ significantly between duplicates or treatments (analysis of covariance, $\mathrm{p}>$ 0.05), and indicate that the assay was equally efficient in detecting target with or without the presence of non-target DNA. The assay was sensitive to as few as 20 copies, and highly linear over 10 orders of magnitude $\left(r^{2}=0.991\right)$. Using the Roche platform and samples from Rhode Island, the assay was linear $\left(\mathrm{r}^{2}=0.995\right)$ between $5 \times 10^{3}$ and $5 \times 10^{8}$ copies (Fig. 2).

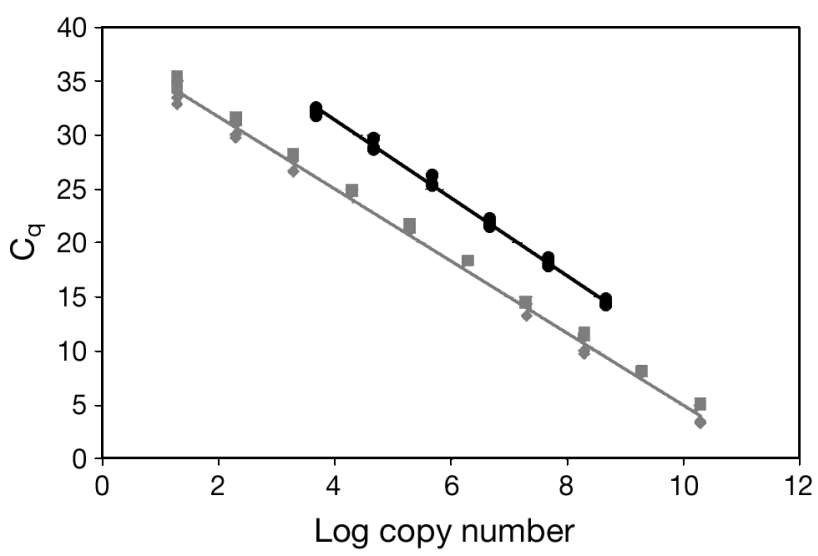

Fig. 2. Haplosporidium nelsoni. Regression lines for DNA copy number vs. quantification cycle $\left(\mathrm{C}_{\mathrm{q}}\right)$. Lower line is the regression (pooled data, $y=-3.34 x+38.31, \mathrm{r}^{2}=0.991$ ) of $\mathrm{C}_{\mathrm{q}}$ against log template copy number for 2 replicates of 2 dilution series $(\diamond, \square)$ from 2 plasmid preparations assayed using the protocols developed in North Carolina. The upper line is the regression (pooled data, $y=-3.36 x+45.71, \mathrm{r}^{2}=0.999$ ) for the 5 dilution series $(\bullet)$ assayed using the protocols developed in Rhode Island

\section{Histological quantification of infected oysters}

qPCR results for the New Jersey oysters using the ABI platform were compared to 2 estimates of infection intensity. The first involved a categorical system in which infections were scored based on a combination of parasite abundance and infection location (Table 1). The correlation with $\mathrm{C}_{\mathrm{q}}$ values derived from the qPCR assay was modest, though significant $\left(r^{2}=0.696, p=<0.0001\right.$; Fig. 3$)$. The correlation using the parasite density as estimated from histological counts was higher and also significant $\left(\mathrm{r}^{2}=0.797, \mathrm{p}<\right.$ 0.0001 ; Fig. 4). The $C_{q}$ values for the highest esti-

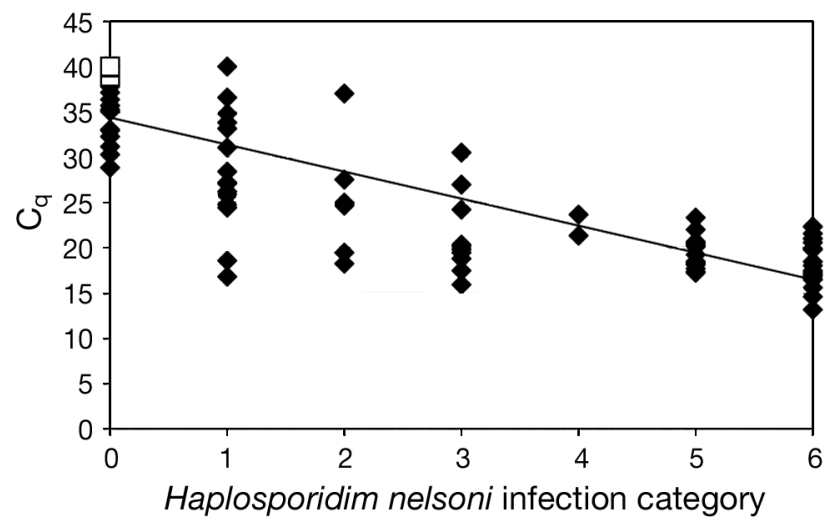

Fig. 3. Crassostrea virginica infected with Haplosporidium nelsoni. Regression of quantification cycle $\left(\mathrm{C}_{\mathrm{q}}\right)$ values against categorical ranking of infections (see Tables 1 \& 2) based on histological examination of infected Delaware Bay oysters $\left(y=-2.99 x+34.04, r^{2}=0.696\right)$. Open squares represent samples of Gulf of Mexico oysters used as negative controls. All quantitative PCR (qPCR) results shown are from the ABI platform

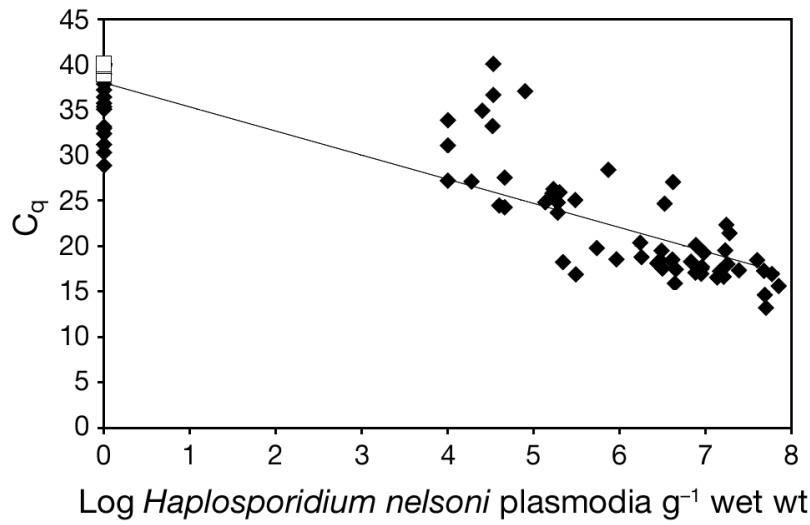

Fig. 4. Crassostrea virginica infected with Haplosporidium nelsoni. Regression of quantification cycle $\left(\mathrm{C}_{\mathrm{q}}\right)$ values against cell counts of $H$. nelsoni determined by histological examination of infected Delaware Bay oysters $(y=-2.65 x+$ $37.98, r^{2}=0.797$ ). Open squares represent samples of Gulf of Mexico oysters used as negative controls. All quantitative PCR (qPCR) results shown are from the ABI platform 
mated densities (Category 6, density from $7.6 \times 10^{6}$ to $7.1 \times 10^{7}$ plasmodia $\mathrm{g}^{-1}$ wet wt, Table 2 ) ranged from 13.2 to 22.2. The $\mathrm{C}_{\mathrm{q}}$ values for the lowest densities (Category 1 , density from $10^{4}$ to $9.2 \times 10^{5}$ plasmodia $\mathrm{g}^{-1}$ wet wt) ranged from 18.5 to 36.6 with an additional sample having no detectable signal $\left(C_{\mathrm{q}}>40\right)$. Of the 15 oysters deemed histologically negative (no detection of plasmodia), only 3 yielded no detectable signal. The remaining 12 had $\mathrm{C}_{\mathrm{q}}$ values ranging from 28.8 to 37.8 . All but 1 had a $\mathrm{C}_{\mathrm{q}}$ value $>30$, and most exhibited values $>35$.

In Rhode Island, the 29 oysters with histologically quantified levels of Haplosporidium nelsoni were evaluated by qPCR using the Roche platform, implementing a threshold of $\mathrm{C}_{\mathrm{q}} \leq 30$ as necessary for identifying positives. Of those 29 oysters, 24 tested either all negative ( 9 oysters) or all positive (15 oysters) by the 3 techniques ( $83 \%$ concordance; Table 3 ). Quantitative PCR was negative for 4 oysters that were positive by both end-point PCR and histology. All 4 of these oysters had light infections restricted to the gills as detected by histology, suggesting that the relatively small sample size used for the qPCR assay missed these light, localized infections. Neither qPCR nor end-point PCR detected the presence of parasites in any oyster that was considered negative

Table 2. Crassostrea virginica infected with Haplosporidium nelsoni. Comparison of categorical ranking of infection (see Table 1) with estimated parasite densities $\left(\mathrm{g}^{-1}\right.$ wet $\left.\mathrm{wt}\right)$ in infected Delaware Bay oysters

\begin{tabular}{|lccc|}
\hline Category & $\begin{array}{c}\text { No. of } \\
\text { tissues } \\
\text { examined }\end{array}$ & $\begin{array}{c}\text { Estimated } \\
\text { mean } \\
\text { density }\end{array}$ & $\begin{array}{c}\text { Estimated } \\
\text { density range }\end{array}$ \\
\hline 1 & 16 & $6.5 \times 10^{4}$ & $10^{4}-9.2 \times 10^{5}$ \\
2 & 7 & $3.3 \times 10^{5}$ & $4.5 \times 10^{4}-3.3 \times 10^{6}$ \\
3 & 8 & $1.7 \times 10^{6}$ & $4.6 \times 10^{4}-1.7 \times 10^{7}$ \\
4 & 2 & $1.9 \times 10^{6}$ & $1.9 \times 10^{5}-1.9 \times 10^{7}$ \\
5 & 11 & $6.5 \times 10^{6}$ & $2.7 \times 10^{6}-2.4 \times 10^{7}$ \\
6 & 13 & $2.4 \times 10^{7}$ & $7.6 \times 10^{6}-7.1 \times 10^{7}$ \\
\hline
\end{tabular}

Table 3. Crassostrea virginica infected with Haplosporidium nelsoni. Comparison of histology, end-point PCR, and quantitative PCR (qPCR) in the detection of H. nelsoni in 29 selected Rhode Island oysters collected in 2007 and 2008. Oysters enumerated were positive $(+)$ or negative $(-)$ by each assay as indicated

\begin{tabular}{|lcccccccc|}
\hline \multicolumn{7}{|c|}{ Concordance of assay outcomes } \\
\hline Histology & - & + & + & + & - & - & - \\
PCR & - & - & + & + & + & + & - \\
qPCR & - & - & - & + & + & - & + \\
No. of oysters & 9 & 1 & 4 & 15 & 0 & 0 & 0 \\
Percentage & 31 & 3 & 14 & 52 & 0 & 0 & 0 \\
\hline
\end{tabular}

by histology. There was a relatively good correspondence between the intensity of $H$. nelsoni as detected by histology and the numbers of $H$. nelsoni copies as detected by qPCR for the 15 oysters that were positive by both methods. Five of 15 positive oysters were classified as light infections by histology and yielded $\mathrm{C}_{\mathrm{q}}$ values between 27 and 30 (suggestive of copy numbers between $10^{4}$ and $10^{5}$ ). Eleven were classified as moderate or heavy by histology, with 9 estimated to have copy numbers between $10^{5}$ and $10^{8}$ $\left(\mathrm{C}_{\mathrm{q}}\right.$ between 10 and 27$)$ and 2 estimated to have copy number $>10^{10}\left(\mathrm{C}_{\mathrm{q}}\right.$ around 8$)$.

\section{Assay application}

In North Carolina, Haplosporidium nelsoni DNA was detected by the qPCR assay in all samples (ABI platform, positive threshold of $\mathrm{C}_{\mathrm{q}}<38$ ). Prevalence ranged from $13 \%$ in Legged Lump to $100 \%$ in Crab Hole and in the smallest size class of oysters from the White Oak River (Table 4, Fig. 1). The vast majority of the estimated infection intensities in summer samples from Pamlico Sound were low $(<2000$ parasites $\mathrm{g}^{-1}$ wet wt). Only a single oyster from West Bluff was estimated to harbor a heavy parasite load $\left(>10^{6}\right.$ parasites $\mathrm{g}^{-1}$ wet wt). Similarly, most oysters sampled from southeastern North Carolina in December exhibited low-intensity infections $(<2000$ parasites $\mathrm{g}^{-1}$ wet $\left.\mathrm{wt}\right)$. The exception occurred in the large size class (>50 mm shell height) collected in Hewletts Creek, where 1 oyster was estimated to harbor $>10^{9}$ parasites $\mathrm{g}^{-1}$ wet wt.

The qPCR assay (Roche platform, positive threshold $\mathrm{C}_{\mathrm{q}} \leq 30$ ) was used to evaluate Haplosporidium nelsoni prevalence in 107 oysters collected in 2009 from 2 locations in Narragansett Bay, Rhode Island, including one location in East Narragansett Bay that had $8 \%$ prevalence in 2007 and $20 \%$ prevalence in 2008. None of these $1 \mathrm{yr}$ old oysters (73 from East Narragansett Bay, 34 from West Narragansett Bay) was positive for $H$. nelsoni by $\mathrm{qPCR}\left(\mathrm{C}_{\mathrm{q}}>30\right)$. A random subset of 38 oysters from these 107 was also tested and determined to be negative by end-point PCR.

\section{DISCUSSION}

We have developed a qPCR assay for the eastern oyster pathogen Haplosporidium nelsoni and compared 
Table 4. Crassostrea virginica infected with Haplosporidium nelsoni. Quantitative PCR (qPCR) assay results for oysters collected in North Carolina. Quantification cycles $\left(\mathrm{C}_{\mathrm{q}}\right)$ above 38 are identified as being undetectable by histology based on the results from the histologically examined New Jersey oysters (see 'Results'). Parasite densities (parasites g ${ }^{-1}$ wet wt) were estimated using the regression equation derived from the histological cell counts (see 'Materials and methods' and Fig. 4) and are reported for positive $\left(\mathrm{C}_{\mathrm{q}}<38\right)$ samples only. All June 2006 samples were from subtidal sites in Pamlico Sound. All December 2006 samples were from intertidal sites

\begin{tabular}{|c|c|c|c|c|c|c|}
\hline Date & Site & $\mathrm{n}$ & $\begin{array}{l}\text { Shell height }(\mathrm{mm}) \\
\quad(\text { mean } \pm \mathrm{SE})\end{array}$ & $\begin{array}{c}\text { No. } \\
\text { positive }\end{array}$ & $\begin{array}{c}\text { No. undetectable } \\
\text { by histology }\end{array}$ & $\begin{array}{c}\text { Estimated density } \\
\text { (parasites } \mathrm{g}^{-1} \text { wet wt) }\end{array}$ \\
\hline \multirow[t]{4}{*}{ Jun 2006} & Buxton & 15 & $83.94 \pm 6.52$ & 3 & 3 & $14.3-1160.0$ \\
\hline & Crab Hole & 15 & $62.16 \pm 4.85$ & 13 & 13 & $5.4-1333.6$ \\
\hline & Legged Lump & 15 & $108.61 \pm 6.22$ & 2 & 2 & $62.9-134.4$ \\
\hline & West Bluff & 15 & $54.14 \pm 5.92$ & 11 & 9 & $51.7-1769927.2$ \\
\hline \multirow[t]{9}{*}{ Dec 2006} & White Oak & 30 & $26.18 \pm 0.55$ & 28 & 28 & $17.7-807.1$ \\
\hline & & 30 & $42.47 \pm 0.97$ & 10 & 10 & $16.6-349.5$ \\
\hline & & 30 & $65.52 \pm 1.73$ & 6 & 6 & $18.5-76.4$ \\
\hline & New River & 30 & $25.92 \pm 0.46$ & 4 & 4 & $23.2-758.0$ \\
\hline & & 30 & $41.28 \pm 0.93$ & 5 & 5 & $13.3-57.0$ \\
\hline & & 30 & $65.52 \pm 1.73$ & 1 & 1 & 19.2 \\
\hline & Hewletts Creek & 30 & $23.79 \pm 0.63$ & 8 & 8 & $16.4-45.3$ \\
\hline & & 30 & $40.44 \pm 0.91$ & 12 & 12 & $13.1-223.7$ \\
\hline & & 30 & $60.10 \pm 1.06$ & 28 & 13 & $16.6-149420730.7$ \\
\hline
\end{tabular}

results against several measures of parasite abundance. As expected, cloned H. nelsoni SSU rRNA produced the typically high regression coefficient $\left(r^{2}=0.99\right)$, and the assay was able to amplify target concentrations of less than $1 \mathrm{fg}$ even in the presence of $200 \mathrm{ng}$ of oyster DNA. The assay demonstrated specificity in that it did not detect other oyster parasites (Perkinsus marinus, Bonamia sp., and H. costale) known to occur on the US east coast. While the precision of the assay was not directly addressed as part of this study, subsequent investigation has shown that the inter-assay variability (same samples run multiple times) is generally 1 cycle or less. Similarly, separate extractions made from pieces of the same tissue clip differ, on average, by less than 1 cycle.

Of more practical importance for this parasite, which has not been grown in culture, are the results of calibration against both categorical ratings and quantitative estimates of parasite abundance in tissue sections. The $\mathrm{r}^{2}$ values of 0.636 and 0.797 for $\mathrm{C}_{\mathrm{q}}$ values versus categorical and density measures, respectively, are modest compared to that found for cloned Haplosporidium nelsoni target region or the 0.826 to 0.99 for calibration curves from cultured Perkinsus marinus (Yarnall et al. 2000, Audemard et al. 2004, Gauthier et al. 2006, De Faveri et al. 2009) and quahog parasite unknown (QPX; Lyons et al. 2006, Liu et al. 2009). Nevertheless, they are significant considering the challenges of accurate parasite quantification in histological samples and the uneven distribution of $H$. nelsoni plasmodia in the tissues, especially in early infections when parasites are localized in the gill or sparsely scattered in the visceral mass (Ford \& Haskin 1982). Gauthier et al. (2006) and De Faveri et al. (2009) also found higher values $\left(r^{2}=\right.$ to 0.897 to 0.948$)$ comparing $\mathrm{qPCR}$ to Ray's fluid thioglycollate medium (RFTM) technique (Ray 1966) and the semi-quantitative rating system (Mackin 1962) for P. marinus-infected tissue smears. Nevertheless, the $H$. nelsoni relationships demonstrate the value of qPCR in providing a useful index to both categorical infection severity and parasite abundance in oyster tissue. Further, extrapolating the regression against parasite density provides an estimate of $H$. nelsoni numbers below (North Carolina) or similar (Rhode Island) to the threshold of reliable detection by histology (calculated to be $\sim 10^{4} \mathrm{~g}^{-1}$ wet wt by Ford et al. 1999).

Two other published studies have compared qPCR data with results from histological sections of oysters, both for parasites in the genus Bonamia (Corbeil et al. 2006, Marty et al. 2006). They compared $C_{\mathrm{q}}$ values with categorical rating systems: essentially none, light, moderate, and heavy. The $\mathrm{C}_{\mathrm{q}}$ values for samples with no parasites detected in histological section could be differentiated statistically from those with light or moderate infections, and light or moderate infections could be distinguished from heavy infections, but within the intermediate categories of light or moderate (Corbeil et al. 2006), and minimal to mild (Marty et al. 2006) $\mathrm{C}_{\mathrm{q}}$ values were statistically indistinguishable. As in these studies, we also found considerable overlap of $\mathrm{C}_{\mathrm{q}}$ values for the Haplosporidium nelsoni infection categories, suggesting that 
even in systemic infections, parasites may not be evenly distributed and/or that estimates of infection intensity are difficult to determine by visual examination of histological sections. Further, the categorical rating system for $H$. nelsoni involves infection location as well as parasite abundance. Thus, the move from Categories $\leq 3$ to Categories $\geq 4$ represents an important change in the severity of infection: the dispersion of parasites from the epithelium (local) into the circulation (systemic) and not always an increase in density. The increasing scatter of $\mathrm{C}_{\mathrm{q}}$ values with decreasing parasite density (Figs. $3 \& 4$ ) is likely due to the difficulty of obtaining reliable estimates of rare or very light infections from histological sections in which parasites are patchily distributed as well as the probability that the small tissue samples analyzed by qPCR will contain yet a different number of parasites.

Our results extend the previously documented distribution limits in North Carolina (Morrison et al. 1992) into southeastern coastal waters of the state. The presence of Haplosporidium nelsoni along the southeastern North Carolina coast is not surprising in that the parasite has been noted in histological/cytological assays of oysters farther to the south (Lewis et al. 1992, Dougherty et al. 1993, Bobo et al. 1996). Bobo et al. (1996) reported the presence of $H$. nelsoni at 10 of 21 stations in South Carolina with prevalence as high as $42 \%$. Lewis et al. (1992) reported H. nelsoni at 4 stations in Georgia with prevalence of 2 to $6 \%$. Using qPCR methodology, we found evidence of H. nelsoni at all 7 sites sampled, with an average prevalence of $54 \%$ (range 13-100\%). Estimated intensities, however, were relatively low with oysters at only 2 sites having infections heavy enough to be histologically detectable (i.e. $>\sim 10^{4}$ parasites $\mathrm{g}^{-1}$ wet wt): $17 \%(15 / 90)$ at Hewletts Creek and $13 \%(2 / 15)$ at West Bluff. Whether the prevalence and evidence of some proliferation of the parasite in North Carolina is indicative of an emerging disease problem is unknown, as the trigger for epizootics is also not known.

The widespread occurrence of Haplosporidium nelsoni and the high prevalence in some North Carolina sites, as determined by $\mathrm{qPCR}$, suggests that it may not be a scarcity of parasites that prevents the development of epizootics. Unfavorable environmental circumstances, like low salinity (Andrews 1983), have been suggested (NCDMF 2008) and may indeed be contributing to the low infection estimates in samples from the Pamlico, where salinities, particularly in the northern reaches, are often low. Low salinity, however, is less likely to explain the lack of development at high salinity sites in southeastern North Carolina. It is interesting to note the difference in estimated intensity between the high salinity sites in the White Oak River and in Hewletts Creek. $\mathrm{C}_{\mathrm{q}}$ values for oysters from the White Oak River were never below the values associated with rare and light infections for oysters from Delaware Bay, but in Hewletts Creek, 12\% (15/90) exhibited $C_{q}$ values consistent with the heavily infected category (Fig. 3). While all of the oysters testing positive by qPCR were not examined by histology, 2 of the heavier infection estimates from Hewletts Creek $\left(\mathrm{HC} 305 \mathrm{C}_{\mathrm{q}}=16.8\right.$, HC312 $C_{q}=17.1$ ) were histologically examined and infection with $H$. nelsoni was confirmed (R. Carnegie pers. comm.). Whether these higher estimated intensities caused mortalities to occur in Hewletts Creek in 2006/2007 is unknown.

The application of the assay was less informative in Rhode Island, where Haplosporidium nelsoni was not detected in the 2009 field samples. Although the assay was less sensitive as it was applied in Rhode Island (the $\mathrm{C}_{\mathrm{q}}$ differed by 8 for the same cloned copy concentrations, and the standard curve flattens out between $\mathrm{C}_{\mathrm{q}} \mathrm{s}$ of 30 and 35), the results from the $\mathrm{qPCR}$ agreed with those obtained by endpoint PCR. The difference in sensitivity between the ABI (North Carolina) and Roche (Rhode Island) platforms may be attributable to the fact that reaction conditions were not thoroughly optimized for the Roche platform, since the assay developed in North Carolina for the ABI platform was used in Rhode Island with few modifications.

These results indicate that $\mathrm{qPCR}$ is a reliable and efficient alternative to traditional histological approaches for the detection of Haplosporidium nelsoni in oysters and for estimating infection intensity. The greater sensitivity usually achieved with qPCR provides the opportunity to investigate the early stages of infection before they are reliably detected by histology, and the efficiency of the assays provides results in a much quicker time frame than histology, allowing for high-throughput processing of samples. As with all PCR-based detection assays, the potential for false positives (either through contamination of the sample or the presence of non-infective parasite or parasite DNA) and false negatives (missed target) prevents the unequivocal diagnosis of a particular sample when infections are less than can be confirmed by other methods. However, such limitations plague all PCR approaches and to some extent even histological approaches (absence of parasites can only be confirmed for the small amount of tissue inspected). The assay described here has the poten- 
tial to greatly expand our understanding of this important parasite and provides a powerful management tool for simultaneously monitoring prevalence and intensity in natural populations.

Acknowledgements. Assay development and application in North Carolina was supported by the UNCW MARBIONC program. Application in Rhode Island was funded by a grant from the Rhode Island Department of Environmental Management. We thank J. Shelton and M. McPhillips for processing and running samples in Rhode Island, E. Scarpa (Haskin Lab) for slide preparation, G. Allen (NCDMF) for Pamlico collections, R. Carnegie (VIMS) for histological confirmation, and M. Smith (UNCW) for Fig. 1.

\section{LITERATURE CITED}

Alves D (2007) Aquaculture in Rhode Island: 2007 yearly status report. Rhode Island Coastal Resources Management Council. Available at www.crmc.ri.gov/ aquaculture.html

Andamari R, Rice MA, Yevich PP (1996) A survey of disease in the oyster Crassostrea virginica (Gmelin, 1971) in Rhode Island coastal estuaries. Wasmann J Biol 51:39-54

Anderson TJ, Adlard RD, Lester RJG (1995) Molecular diagnosis of Marteilia sydneyi (Paramyxea) in Sydney rock oysters, Saccostrea commercialis (Angas). J Fish Dis 18: 507-510

Andrews JD (1961) Measurement of shell growth in oysters by weighing in water. Proc Natl Shellfish Assoc 52:1-11

> Andrews JD (1983) Minchinia nelsoni (MSX) infections in the James River seed-oyster area and their expulsion in spring. Estuar Coast Shelf Sci 16:255-269

Audemard C, Reece KS, Burreson EM (2004) Real-time PCR for detection and quantification of the protistan parasite Perkinsus marinus in environmental waters. Appl Environ Microbiol 70:6611-6618

Audemard C, Calvo LMR, Paynter KT, Reece KS, Burreson EM (2006) Real-time PCR investigation of parasite ecology: in situ determination of oyster parasite Perkinsus marinus transmission dynamics in lower Chesapeake Bay. Parasitology 132:827-842

Barber BJ, Langan R, Howell TL (1997) Haplosporidium nelsoni (MSX) epizootic in the Piscataqua River estuary (Maine/New Hampshire, USA). J Parasitol 83:148-150

Bobo MY, Richardson D, Cheng TC, McGovern E, Coen L (1996) Season cycle of Haplosporidium nelsoni (MSX) in intertidal oysters, Crassostrea virginica, in South Carolina. J Shellfish Res 15:525 (Abstract)

Burreson EM, Robinson ME, Villalba A (1988) A comparison of paraffin histology and hemolymph analysis for the diagnosis of Haplosporidium nelsoni (MSX) in Crassostrea virginica (Gmelin). J Shellfish Res 7:19-24

> Bustin SA, Vladimir B, Garson JA, Hellemans J and others (2009) The MIQE guidelines: minimum information for publication of quantitative real-time PCR experiments. Clin Chem 55:611-622

> Carnegie RB, Meyer GR, Blackbourn J, Cochennec-Laureau N, Berthe FCJ, Bower SM (2003) Molecular detection of the oyster parasite Mikrocytos mackini, and a preliminary phylogenetic analysis. Dis Aquat Org 54:219-227

Carnegie RB, Stokes NA, Audemard C, Bishop MJ and others (2008) Strong seasonality of Bonamia sp. infection and induced Crassostrea ariakensis mortality in Bogue and Masonboro Sounds, North Carolina, USA. J Invertebr Pathol 98:335-343

Cooper KR, Durfee W (1982) A one-year disease survey of four commercially important Rhode Island bivalve mollusks: Mya arenaria, Argopecten irradians irradians, Crassostrea virginica, and Mercenaria mercenaria. J Shellfish Res 2:93 (Abstract)

> Corbeil S, Arzul I, Diggles B, Heasman M, Chollet B, Berthe FCJ, Crane MS (2006) Development of a TaqMan PCR assay for the detection of Bonamia species. Dis Aquat Org 71:75-80

> Day JM, Franklin DE, Brown BL (2000) Use of competitive PCR to detect and quantify Haplosporidium nelsoni infection (MSX disease) in the eastern oyster (Crassostrea virginica). Mar Biotechnol 2:456-465

$>$ De Faveri J, Smolowitz R, Roberts RB (2009) Development and validation of a real-time quantitative PCR assay for the detection and quantification of Perkinsus marinus in the eastern oyster, Crassostrea virginica. J Shellfish Res 28:459-464

Dougherty WJ, Cheng TC, Burrell VG, Jr (1993) Occurrence of the pathogen Haplosporidium nelsoni in oysters, Crassostrea virginica, in South Carolina, USA. Trans Am Microsc Soc 112:75-77

Farley CA (1968) Minchinia nelsoni (Haplosporida) disease syndrome in the American oyster Crassostrea virginica. J Protozool 15:585-599

Fong D, Chan MM, Rodriguez R, Chen CC, Liang Y, Littlewood DTJ, Ford SE (1993) Small subunit ribosomal RNA gene sequence of the parasitic protozoan Haplosporidium nelsoni provides a molecular probe for the oyster MSX disease. Mol Biochem Parasitol 62:139-142

Ford SE, Haskin HH (1982) History and epizootiology of Haplosporidium nelsoni (MSX), an oyster pathogen, in Delaware Bay, 1957-1980. J Invertebr Pathol 40:118-141

Ford SE, Haskin HH (1987) Infection and mortality patterns in strains of oysters Crassostrea virginica selected for resistance to the parasite Haplosporidium nelsoni (MSX). J Parasitol 73:368-376

Ford S, Powell E, Klinck J, Hofmann E (1999) Modeling the MSX parasite in eastern oyster (Crassostrea virginica) populations. I. Model development, implementation, and verification. J Shellfish Res 18:475-500

Ford SE, Allam B, Xu Z (2009a) Using bivalves as particle collectors and PCR detection to investigate the environmental distribution of Haplosporidium nelsoni. Dis Aquat Org 83:159-168

Ford SE, Stokes NA, Burreson EM, Scarpa E, Carnegie RB, Kraeuter JN, Bushek D (2009b) Minchinia mercenariae $\mathrm{n}$ sp., a parasite of the hard clam Mercenaria mercenaria: implications of a rare parasite. J Eukaryot Microbiol 56: 542-551

Ford SE, Paterno J, Scarpa E, Stokes NA, Kim Y, Powell EN, Bushek D (2011) Widespread survey finds no evidence of Haplosporidium nelsoni (MSX) in Gulf of Mexico oysters. Dis Aquat Org 93:251-256

> Gast RJ, Moran DM, Audemard C, Lyons MM and others (2008) Environmental distribution and persistence of Quahog Parasite Unknown (QPX). Dis Aquat Org 81: 219-229

Gauthier JD, Miller CR, Wilbur AE (2006) TaqMan ${ }^{\circledR}$ MGB real-time PCR approach to quantification of Perkinsus marinus and Perkinsus spp. in oysters. J Shellfish Res 25: $619-624$ 
Haskin HH, Andrews JD (1988) Uncertainties and speculations about the life cycle of the eastern oyster pathogen Haplosporidium nelsoni (MSX). In: Fisher WS (ed) Disease processes in marine bivalve molluscs, Vol 18. American Fisheries Society, Bethesda, MD, p 5-22

Kim Y, Powell EN (2007) Distribution of parasites and pathologies in sentinel bivalves: NOAA status and trends 'Mussel Watch' program. J Shellfish Res 26:1115-1151

Krantz EL, Buchanan LR, Farley CA, Carr AH (1972) Minchinia nelsoni in oysters from Massachusetts waters. Proc Natl Shellfish Assoc 62:83-88

Kutyavin I, Afonina I, Mills A, Gorn V and others (2000) 3'-Minor groove binder DNA probes increase sequence specificity at PCR extension temperatures. Nucleic Acids Res 28:655-661

Lewis EJ, Kern FG, Rosenfield A, Stevens SA, Walker RL, Heffernan PB (1992) Lethal parasites in oysters from coastal Georgia, with discussion of disease and management implications. Mar Fish Rev 52:1-6

Liu Q, Allam B, Collier JL (2009) Quantitative real-time PCR assay for QPX (Thraustochytriidae), a parasite of the hard clam (Mercenaria mercenaria). Appl Environ Microbiol 75:4913-4918

Lyons MM, Ward JE, Smolowitz R, Uhlinger KR, Gast RJ (2005) Lethal marine snow: pathogen of bivalve mollusc concealed in marine aggregates. Limnol Oceanogr 50: 1983-1988

Lyons MM, Smolowitz R, Dungan CF, Roberts SB (2006) Development of a real time quantitative PCR assay for the hard clam pathogen Quahog Parasite Unknown (QPX). Dis Aquat Org 72:45-52

Mackin JG (1962) Oyster diseases caused by Dermocystidium marinum and other microorganisms in Louisiana. In: Mackin JG, Hopkins SH (eds) Studies on oysters in relation to the oil industry, Vol 7. Publication of the Institute of Marine Science, Texas A\&M University, College Station, TX, p 132-229

> Marty GD, Bower SM, Clarke KR, Meyer G and others (2006) Histopathology and a real-time PCR assay for detection of Bonamia ostreae in Ostrea edulis cultured in western Canada. Aquaculture 261:33-42

Matthiessen GC, Feng SY, Leibovitz L (1990) Patterns of MSX (Haplosporidium nelsoni) infection and subsequent mortality in resistant and susceptible strains of the eastern oyster Crassostrea virginica (Gmelin, 1791) in New England. J Shellfish Res 9:359-366

Morrison NM, Marshall MD, Dykstra MJ, Levine JF (1992) Haplosporidium nelsoni (MSX) in eastern oyster populations of North Carolina. J Aquat Anim Health 4:203-206

NCDMF (North Carolina Division of Marine Fisheries) (2008) Fisheries management plan: oyster. North Carolina Division of Marine Fisheries, Morehead City, NC

Penna MS, Khan M, French RA (2001) Development of a multiplex PCR for the detection of Haplosporidium nel-

Editorial responsibility: Mike Hine,

Fouras, France soni, Haplosporidium costale and Perkinsus marinus in the eastern oyster (Crassostrea virginica, Gmelin, 1971). Mol Cell Probes 15:385-390

> Ragone Calvo LM, Calvo GW, Burreson EM (2003) Dual disease resistance in a selectively bred eastern oyster, Crassostrea virginica, strain tested in Chesapeake Bay. Aquaculture 220:69-87

Ray SM (1966) A review of the culture method for detecting Dermocystidium marinum, with suggested modifications and precautions. Proc Natl Shellfish Assoc 54:55-69

Robledo JAF, Gauthier JD, Coss CA, Wright AC, Vasta GR (1998) Species-specificity and sensitivity of a PCR-based assay for Perkinsus marinus in the eastern oyster, Crassostrea virginica: a comparison with the fluid thioglycollate assay. J Parasitol 84:1237-1244

Rozen S, Skaletsky H (2000) Primer3 on the WWW for general users and for biologist programmers. Methods Mol Biol 132:365-386

Siddall ME, Aguado MT (2006) Molecular phylogenetic evidence of a haplosporidian parasite infecting the polychaete Syllis nipponica (Imajima, 1966). Parasitol Res 99: 309-312

Stephenson MF, McGladdery SE, Maillet M, Veniot A, Meyer G (2003) First reported occurrence of MSX in Canada. J Shellfish Res 22:355 (Abstract)

Stokes NA, Burreson EM (2001) Differential diagnosis of mixed Haplosporidium costale and Haplosporidium nelsoni infections in the eastern oyster, Crassostrea virginica, using DNA probes. J Shellfish Res 20:207-213

Stokes NA, Siddall ME, Burreson EM (1995) Detection of Haplosporidium nelsoni (Haplosporidia, Haplosporidiidae) in oysters by PCR amplification. Dis Aquat Org 23: 145-152

Sunila I, Karolus J, Volk J (1999) A new epizootic of Haplosporidium nelsoni (MSX), a haplosporidian oyster parasite, in Long Island Sound, Connecticut. J Shellfish Res 18:169-174

Tun KL, Shimizu Y, Yamanoi H, Yoshinaga T, Ogawa K (2008) Seasonality in the infection and invasion of Marteilioides chungmuensis in the Pacific oyster Crassostrea gigas. Dis Aquat Org 80:157-165

Ulrich PN, Ewart JW, Marsh AG (2007a) Prevalence of Perkinsus marinus (dermo), Haplosporidium nelsoni (MSX), and QPX in bivalves of Delaware's inland bays and quantitative, high-throughput diagnosis of dermo by qPCR. J Eukaryot Microbiol 54:520-526

Ulrich PN, Colton CM, Hoover CA, Gaffney PM, Marsh AG (2007b) Haplosporidium nelsoni (MSX) rDNA detected in oysters from the Gulf of Mexico and the Caribbean Sea. J Shellfish Res 26:195-199

> Yarnall HA, Reece KS, Stokes NA, Burreson EM (2000) A quantitative competitive polymerase chain reaction assay for the oyster pathogen Perkinsus marinus. J Parasitol 86:827-837

Submitted: May 2, 2012; Accepted: October 9, 2012 Proofs received from author(s): December 18, 2012 